Japan. J. Trop. Med., Vol. 10, 198-204, 1969

\title{
ON THE PREPARATION OF THE INACTIVATED JAPANESE ENCEPHALITIS VACCINE WITH THE USE OF ALCOHOL-PROTAMINE (AP) PARTIALLY PURIFIED VIRUS
}

\author{
JUNJI NAKAMURA \\ Nippon Institute for Biological Science, Akebono-cho, Tachikawa, Tokyo
}

The author engaged, during the years from 1948 to 1956, in the production of formalin-inactivated JE vaccine of infected chick embryo origin for animal use. Meanwhile, various factors for the better growth of the virus in the embryo were investigated, although the average virus titer of the material obtained under the best available conditions was about $1 \log$ lower than that of the infected mouse brain. Consequently, 10 times more tissular material was required for the production of a chick embryo vaccine which had an immunizing effect comparable with a mouse brain vaccine.

Another effort then made was to establish a practicable method of partial purification of virus from the infected chick embryo suspension. The cold alcohol precipitation of the virus, the removal of non-viral protein by adsorption onto $\mathrm{Al}(\mathrm{OH})_{3}$ gel and the sedimentation of the virus by the Sharples centrifuge were

Table 1. Japanese Encephalitis: Mass Purification of Chick Embryo Virus

\begin{tabular}{|c|c|c|c|c|c|c|c|c|c|}
\hline \multirow{3}{*}{ Treatment } & & \multirow{3}{*}{$\begin{array}{l}\text { No. of } \\
\text { samples }\end{array}$} & \multirow{2}{*}{\multicolumn{3}{|c|}{$\begin{array}{l}\text { Nitrogen content } \\
: \mathrm{mg} / \mathrm{ml}(\mathrm{T} 10 \%)\end{array}$}} & \multicolumn{4}{|c|}{ Infectivity: $\mathrm{LD}_{50} / 0.03(\mathrm{~T} 100 \%)$} \\
\hline & & & & & & \multirow{2}{*}{ Bef. } & \multirow{2}{*}{ Aft. (Dc*) } & \multirow{2}{*}{$\begin{array}{l}\text { Reco- } \\
\text { very } \%\end{array}$} & \multirow{2}{*}{$\begin{array}{l}\text { Purif. } \\
\text { coef. }\end{array}$} \\
\hline & & & Bef. & Aft. & $\%$ & & & & \\
\hline $\begin{array}{l}\text { Alcohol } \\
\text { at } 4^{\circ} \mathrm{C} \\
\text { (Precipitate) }\end{array}$ & $\begin{array}{r}\% \\
5 \\
10 \\
15 \\
20 \\
25\end{array}$ & $\begin{array}{r}5 \\
8 \\
6 \\
15 \\
3\end{array}$ & $\begin{array}{l}0.87 \\
0.84 \\
0.85 \\
0.83 \\
0.78\end{array}$ & $\begin{array}{l}0.05 \\
0.15 \\
0.22 \\
0.27 \\
0.41\end{array}$ & $\begin{array}{r}5 \\
18 \\
26 \\
35 \\
53\end{array}$ & $\begin{array}{l}5.6 \\
6.0 \\
5.9 \\
5.9 \\
6.0\end{array}$ & $\begin{array}{l}4.6(6.0) \\
5.5(5.9) \\
5.7(5.7) \\
6.0(5.4) \\
5.4(4.9)\end{array}$ & $\begin{array}{r}9 \\
50 \\
75 \\
152 \\
30\end{array}$ & $\begin{array}{l}2.2 \\
2.3 \\
3.2 \\
4.4 @ 3 \\
0.4\end{array}$ \\
\hline $\begin{array}{c}\mathrm{Al}(\mathrm{OH})_{3} \text { gel } \\
\text { (Unadsorbed) }\end{array}$ & $\begin{array}{c}\mathrm{mg} / \mathrm{ml} \\
30 \\
40 \\
50\end{array}$ & $\begin{array}{r}17 \\
4 \\
5\end{array}$ & $\begin{array}{l}0.90 \\
1.03 \\
1.05\end{array}$ & $\begin{array}{l}0.20 \\
0.16 \\
0.21\end{array}$ & $\begin{array}{l}22 \\
15 \\
11\end{array}$ & $\begin{array}{l}5.9 \\
5.5 \\
5.6\end{array}$ & $\begin{array}{l}5.2 \\
4.7 \\
4.9\end{array}$ & $\begin{array}{l}74 \\
32 \\
34\end{array}$ & $\begin{array}{l}3.2 @ \\
2.2 \\
3.2\end{array}$ \\
\hline Sharples & $\begin{array}{c}\mathrm{ml} / \mathrm{min} \\
3-20 \\
28-33 \\
90-120\end{array}$ & $\begin{array}{l}5 \\
3 \\
2\end{array}$ & $\begin{array}{l}0.74 \\
0.82 \\
1.01\end{array}$ & $\begin{array}{l}0.10 \\
0.10 \\
0.08\end{array}$ & $\begin{array}{r}15 \\
14 \\
8\end{array}$ & $\begin{array}{l}5,8 \\
5.7 \\
5.7\end{array}$ & $\begin{array}{l}6.0(4.7) \\
5.3(5.4) \\
4.8(5.6)\end{array}$ & $\begin{array}{r}245 \\
40 \\
14\end{array}$ & $\begin{array}{l}15.8 @ \\
3.0 \\
1.8\end{array}$ \\
\hline
\end{tabular}

Alcohol precipitation: Ten-40\% tissular extract was mixed with cooled ethanol, and centrifuged after being left for 4 hours at $4^{\circ} \mathrm{C}$. The sediment was disolved for virus.

$\mathrm{A} 1(\mathrm{OH})_{3}$ gel adsorption: Forty $\%$ tissular extract was mixed with the gel sediment, and centrifuged after being left for 2 hours at $4^{\circ} \mathrm{C}$. The supernatant was used as virus.

Sharples centrifugation: Twenty $\%$ tissular extract preliminarily passed 200 $\mathrm{ml} / \mathrm{min}$ at $30000 \mathrm{rpm}$ was recentrifuged at $50000 \mathrm{rpm}$ with given flowing rates.

(a): The best value. 
the main procedures selected for the purpose. Results of repeated trials are summarized in Table 1, and lead to the following conclusions :

1) The virus was precipitated with little loss from the suspension by treatment with $20 \%$ ethanol at low temperature. The resuspended virus was on an average 4.4 times purified as determined by total nitrogen content and infectivity titer.

2) When the suspension was treated with $30 \mathrm{mg} / \mathrm{ml}$ of $\mathrm{Al}(\mathrm{OH})_{3}$ gel, $74 \%$ of virus remained unadsorbed in the supernatant fluid, and was found 3.2 times purified on an average.

3) When the suspension was subjected to the Sharples centrifuge with a feed rate of $3-20 \mathrm{ml} / \mathrm{min}$ and a centrifuge force of $50,000 \mathrm{rpm}$, the virus was recovered in the sediment with no loss and purified 15.8 times on an average.

Any of these procedures was not employed practically in the production of commercial chick embryo vaccine for animal use since such an additional process should make the cost of the product intolerably high. However, the procedure of alcohol precipitation was subsequently applied to the partial purification of mouse brain virus, and was combined with the protamine-sulfate treatment to develope the alcohol-protamine (AP) method. A paper on the study of this

Table 2. Japanese Encephalitis: Preparation of AP-Purified Vaccine

1. Method

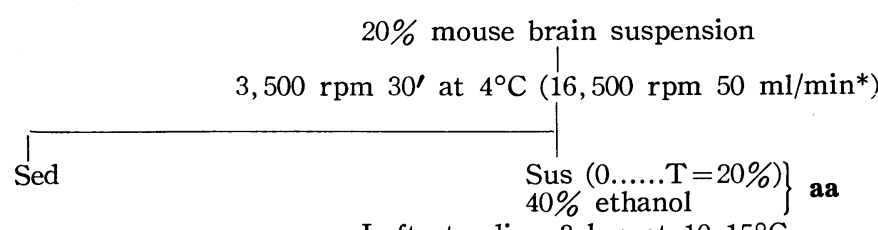

Left standing $3 \mathrm{hrs}$ at $10-15^{\circ} \mathrm{C}$
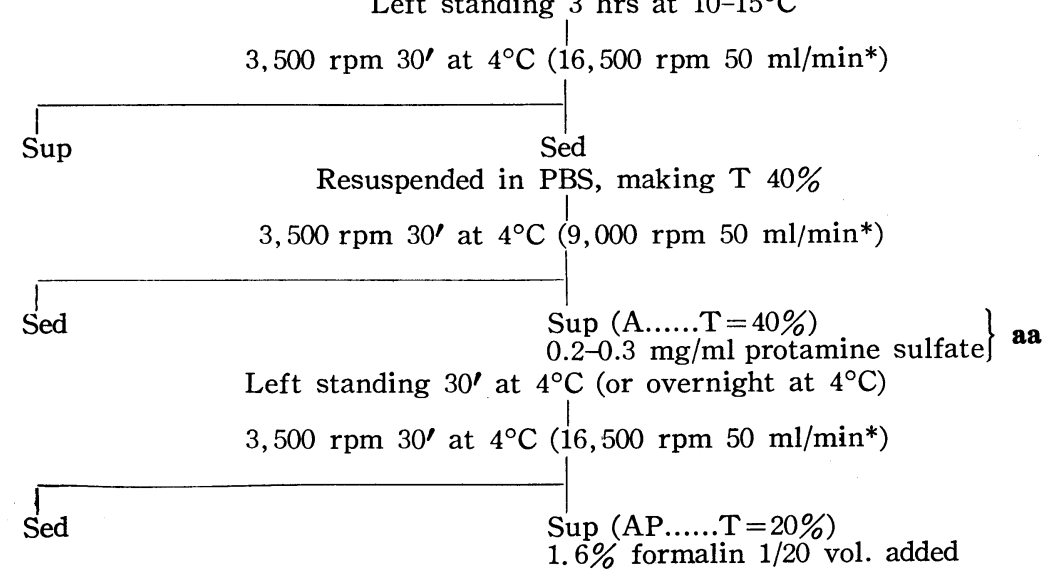

10 days in refrigerator, shaken ones a day,

Further 11 days left standing in refrigerator

Filtered through millipore filter (type: SS, size: $3 \mu$ ),

diluted with 3 volumes of PBS, and added

ethylmercurithiosalicylate $0.01 \mathrm{~W} / \mathrm{V} \%$ and tween $800.05 \%$

* By continuous-flow centrifuge. 
method and its application to the preparation of a partially purified formalin inactivated mouse brain vaccine was printed and distributed personally in 1963, and the method has been applied since 1966 to the production of commercial vaccine for human use in different laboratories in this country. The method is given in Table 2.

In the first step of virus purification, the centrifuged $20 \%$ mouse brain suspension is mixed with an epual volume of $40 \%$ ethanol and precipitation is allowed to occur at $10-15^{\circ} \mathrm{C}$. This temperature range was found as the most suitable for getting the best purification effect from results of repeated comparisons of graded temperatures between 5 and $45^{\circ} \mathrm{C}$. In the second step, protamine sulfate is added to the resuspended virus in order to precipitate the nonviral protein. The partially purified virus is inactivated by keeping in an ordinary refrigerator under addition of formalin.

The effect of purification is determined either on the infectivity (50\% lethal dilution or $\log \mathrm{LD}_{50}$ ) of fresh material or on the immunizing effect (50\% mouse protective dilution or $\log _{4} \mathrm{ED}_{50}$ ) of inactivated material, taking a definite amount of total nitrogen for the base of comparison. The data obtained are summarized respectively for the early time experiments carried out in a small scale, for the later experiments in a larger scale, and for the lots of commercial product prepared in Nisseiken Laboratory in 1968. Mean values for each items in each series are given in Table 3.

" $\mathrm{O}$ " in the table represents the samples obtained after the primary centrifugation, "A" after the ethanol treatment, and "AP" after the protamine sulfate treatment. Results are summarized as follows:

1) In the small scale experiments, nitrogen remained at a rate of $15.2 \%$ in

Table 3. Japanese Encephalitis: Preparation of AP-Purified Vaccine

2. Results

\begin{tabular}{|c|c|c|c|c|c|c|c|c|c|c|c|}
\hline \multirow{3}{*}{$\begin{array}{l}\text { Scale of } \\
\text { Pre- } \\
\text { paration }\end{array}$} & \multicolumn{3}{|c|}{ Nitrogen Content } & \multicolumn{4}{|c|}{ Infectivity } & \multicolumn{4}{|c|}{ Immunogenic Activity } \\
\hline & No. of & Aver & cage & \multirow{2}{*}{$\begin{array}{c}\text { No. of } \\
\text { sam- } \\
\text { ples }\end{array}$} & \multicolumn{3}{|c|}{ Average } & \multirow{2}{*}{$\begin{array}{c}\text { No. of } \\
\text { sam- } \\
\text { ples }\end{array}$} & \multicolumn{3}{|c|}{ Average } \\
\hline & $\begin{array}{l}\text { sam- } \\
\text { ples }\end{array}$ & $\mathrm{mg} / \mathrm{ml}$ & $\begin{array}{c}\text { Resi- } \\
\text { due } \\
\%\end{array}$ & & $\begin{array}{l}\mathrm{LD}_{50} \\
\text { for } \\
\text { mice }\end{array}$ & $\begin{array}{c}\text { Reco- } \\
\text { very } \\
\% \\
\end{array}$ & $\begin{array}{l}\text { Purifi- } \\
\text { cation } \\
\text { coef. }\end{array}$ & & $\begin{array}{c}\mathrm{ED}_{50} \\
\left(\log _{4}\right)\end{array}$ & $\begin{array}{l}\text { Reco- } \\
\text { very } \\
\%\end{array}$ & $\begin{array}{l}\text { Purifi- } \\
\text { cation } \\
\text { coef. }\end{array}$ \\
\hline \multirow{3}{*}{$\begin{array}{l}\text { Small } \\
\text { exper. } \\
\text { scale }\end{array}$} & 8 & 0.750 & 100.0 & 8 & 7.6 & 100 & 1.0 & 3 & 2.44 & 100 & 1.0 \\
\hline & 8 & 0.114 & 15. 2 & 8 & 7.4 & 63 & 4.1 & 3 & 2.46 & 103 & 6.3 \\
\hline & 7 & 0.030 & 4.2 & 7 & 7.2 & 40 & 9.5 & 3 & 2.08 & 62 & 14.8 \\
\hline \multirow{3}{*}{$\begin{array}{l}\text { Large } \\
\text { exper. } \\
\text { scale }\end{array}$} & 4 & 0.831 & 100.0 & & & & & 4 & 2.32 & 100 & 1.0 \\
\hline & 4 & 0.058 & 7.3 & & & & & 4 & 2.12 & 70 & 9.6 \\
\hline & 4 & 0.020 & 2.7 & & & & & 4 & 1.95 & 65 & 26.3 \\
\hline \multirow{3}{*}{$\begin{array}{l}\text { Commer- O } \\
\text { cial lots A } \\
\text { (1968) A P }\end{array}$} & 29 & 0.961 & 100.0 & 29 & 7.8 & 100 & 1.0 & & & & \\
\hline & 29 & 0.078 & 8.1 & 29 & 7.4 & 40 & 4.9 & & & & \\
\hline & 29 & 0.025 & 2.7 & 29 & 7.4 & 40 & 14.8 & 22 & 2.47 & & \\
\hline
\end{tabular}

Figures represent values for samples at concentration corresponding to $\mathrm{T} 10 \%$. $\mathrm{ED}_{50}$ expresses $50 \%$ mouse protective dilution by four repeated intraperitoneal doses of $0.5 \mathrm{ml}$ against intracerebral challenge by $10-15 \mathrm{LD}_{50}$ of virus. 
$\mathrm{A}$ and $4.2 \%$ in AP while infectivity was recovered at a rate of $63 \%$ in $\mathrm{A}$ and $40 \%$ in AP. Therefore, apparent purification factors were 4.1 and 9.5 for A and AP, respectively. The immunizing substance was recovered at a rate of $103 \%$ in $\mathrm{A}$ and $62 \%$ in $\mathrm{AP}$ and, consequently, the purification factors on this property were calculated as 6.8 and 14.8 respectively for A and AP.

2) In the larger scale experiments, nitrogen content was more reduced in both steps of purification, so the remaining rates being $7.3 \%$ in $\mathrm{A}$ and $2.7 \%$ in AP. The purification factors pertaining to the immunizing property increased accordingly, and were found as 9.6 and 26.3 respectively.

3) Grades of decrease in nitrogen content in the commercial lots were nearly on a level with those in the samples in the larger scale experiments, remaining rates being 8.1 and $2.7 \%$ respectively in A and AP. The purification factors pertaining to the infectivity were 4.9 in A and 14.8 in AP which are considerably greater than those obtained in the small scale experiments. The purification factors pertaining to the immunizing property were not available because of the lack of tests with 0 and A samples, although the average protective value 2.47 is on a level with or even somewhat higher than those obtained with the experimental samples.

Recent studies made by the NIH team and some other workers have raised a problem of some slight antigenic strain differences of Japanese encephalitis virus. Two types represented respectively by the Nakayama-Yoken strain and the JaGAr-01 strain and the third and intermediate of the two have been roughly classified so far, and the JaGAr-01 type has been regarded as the most common among strains isolated in recent years in this country. Nevertheless, the Nakayama-Yoken strain has been empleyed since the earliest time up to date for both production and assay of the man's vaccine.

Reasons why no JaGAr-01 type vaccine has yet come to the practical use appear to exist in the following:

1) Further studies on the strain differences are still needed from both serologic and epidemiologic aspects.

2) Field trials in man of the JaGAr-01 type vaccine have been still scarce.

3) A relatively constant yield of vaccine products of high potency has been promised from many years' experience in the past with the use of the NakayamaYoken strain infected mouse brains. Also this strain has been long trusted on as an assay virus which gave relatively little irregularities and discrepansies in results. On the other hand, any JaGAr-01 type strains which may give comparable or better results either as a vaccine seed virus or a challenge virus have not yet been introduced with reasonable amounts of data and experience.

Our interest in these several years has been in the establishment of a system of production and assay of the JaGAr-01 type vaccine. The following data are from some of our concerning experiments.

Using the Nakayama-Yoken strain, the JaGAr-01 strain and two other JaGAr01 type strains, T8 and YS which had been selected among many by their relatively strong mouse immunizing property demonstrated in preliminary experiments, AP vaccines were prepared two lots for each strain. In experiments of Fig. 1 and Fig. 2, the first and second series of the four different strain vaccines were subjected to the potency test by challenging vaccinated mice crossly 
Fig. 1. Japanese Encephalitis: Mouse Protective Values of Different Strain AP Vaccines against Homologous and Heterologous Strain Viruses. (Experiment 1)

AP-Vaccine prepared with strain :

Naka. JaGAr. YS T8
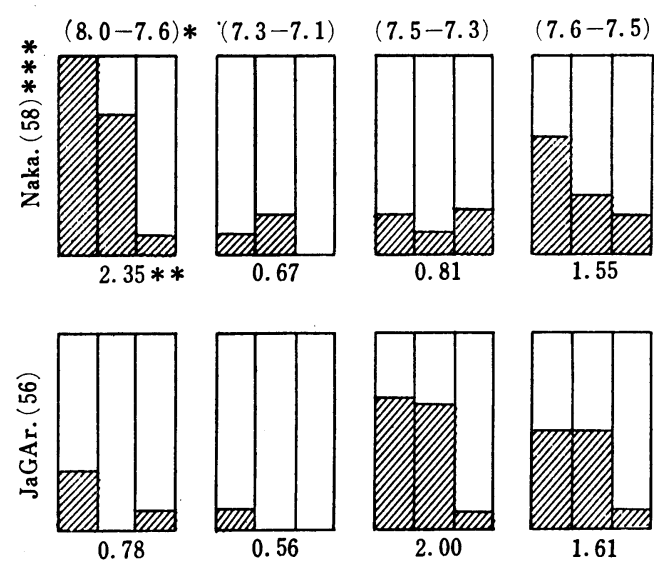

$* \log \mathrm{LD}_{5_{0}} / 0.03$ of material before (8.0) and after(7.6) purification.

$* * \log _{4} \mathrm{ED}_{50}(2.35)$ determined with 3 dilutions of $\mathrm{T} 5 \%$ vaccine $(4,16 \& 64)$.
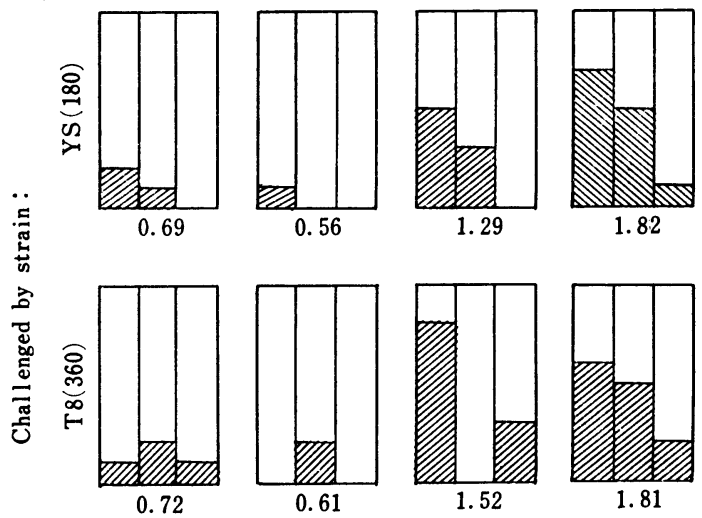

$* * *$ Challenge dose $(58)$ of virus in $\mathrm{LD}_{50}$.

VIIIIS : Percentage of mice survived the challenge ( $8-$ 10 mice were challenged for each dilution).

$\square$ : Percentage of mice died of challenge.
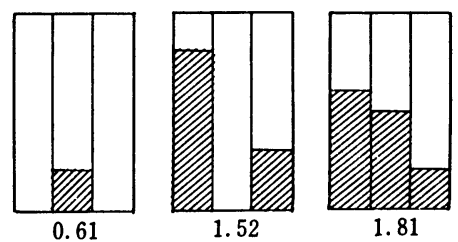

against homologous and heterologous viruses. The test method was similar to what is used in routine in the national assay of commercial products only with exception that different strain viruses were used for the challenge.

The results show:

1) No distinct antigenic difference was demonstrated between the JaGAr01 , the YS and the T8 strain. The Nakayama-Yoken strain differed considerably from the other three.

2) Roughly judged, the vaccines prepared with the YS and T8 strains gave nearly the same level protection against the JaGAr-01 type viruses as the Nakayama-Yoken vaccine did against its homologous virus. The vaccine prepared with the JaGAr-01 strain was, however, obviously less effective. Its first lot had almost no protective value and its second was effective with relatively low titers only against its own and T8 strains. 
Fig. 2. Japanese Encephalitis: Mouse Protective Values of Different Strain AP Vaccines against Homologous and Heterologous Strain Viruses. (Experiment 2)

AP vaccine prepared with strain:

Naka. JaGAr. YS T8
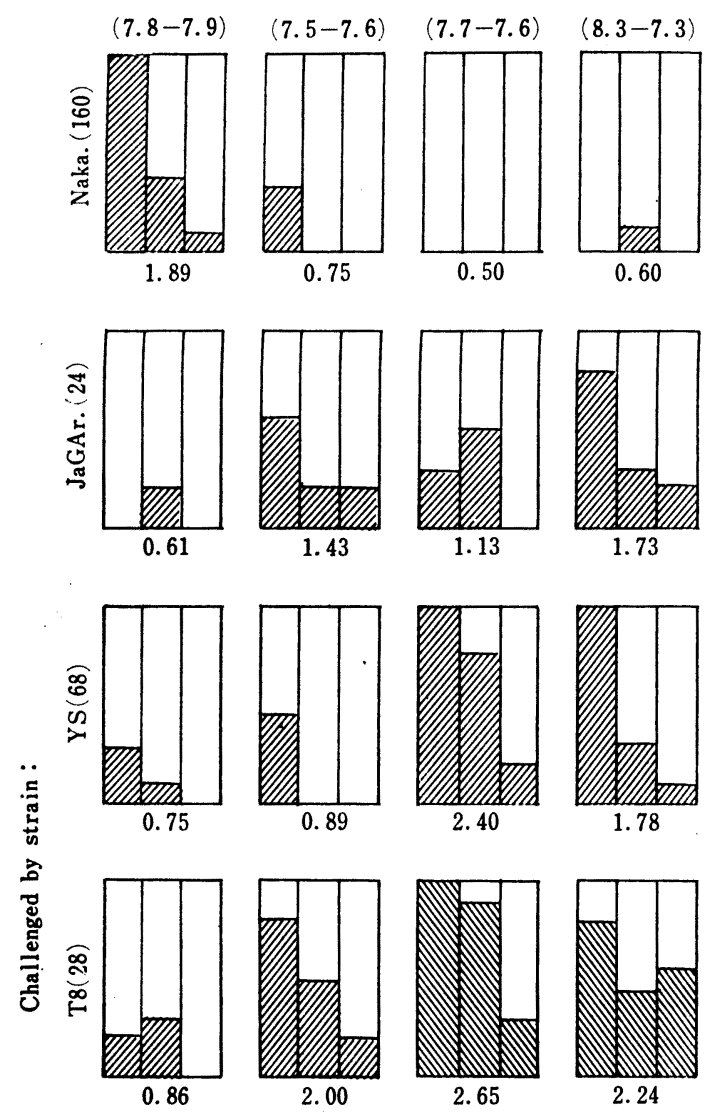

Starting from the same original strain "Nakayama" isolated in 1935, the "Yoken" line have been maintained since the end of World War II, in the National Institute of Health while the "Yakken" line nearly so long in the National Veterinary Assay Laboratory. The two lines are said to be serologically not identical. The Fig. 3 experiment was planned to see how the NakayamaYakken vaccine which has been issued for animal use for many years behaves against the two types of the virus. For this purpose, an AP vaccine newly prepared with the Nakayama-Yakken strain, and the Nakayama-Yoken and T8 Vaccines preveously used in Experiment 1 were comparatively tested against homologous and heterologous viruses.

So far as the antigenicity determined in this type of test concerned, the Nakayama-Yakken strain was much more related to the T8 strain than to the Nakayama-Yoken strain, and is regarded to belong rather to the JaGAr-01 type. 
Fig. 3. Japanese Encephalitis: Mouse Protective Values of Different Strain AP Vaccines againts Homologous and Heterologous Strain Viruses. (Experiment 4)

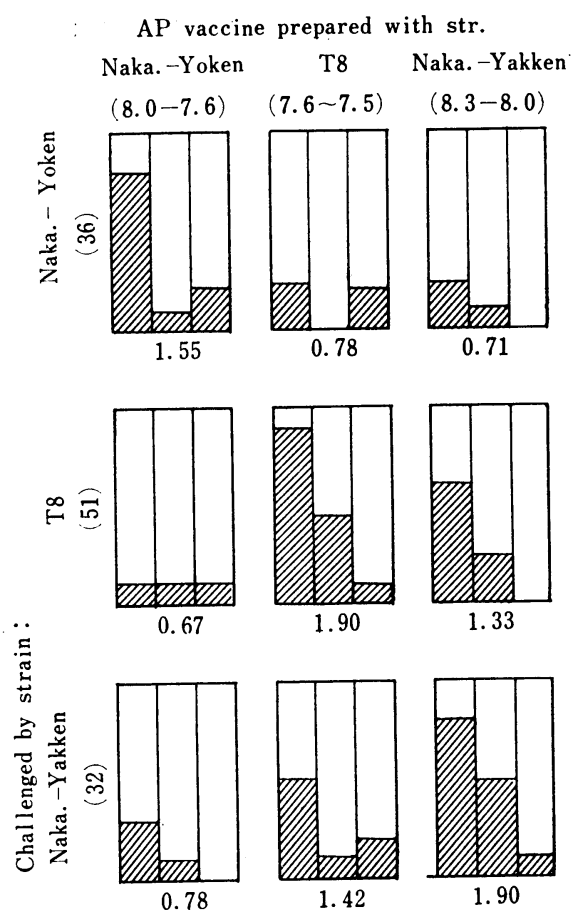

When and how such a variation was introduced between the two lines of the Nakayama strain is obscure.

In parallel, antigenic differences among the strains are also being studied by cross virus neutralization experiments with immunized mouse serums. From results obtained so far, the difference was distinct between Nakayama-Yoken strain and other strains although the overlapping of the two types appeared to be more emphasized than in the cross resistance experiments.

From the technical point of view, the production of an AP vaccine of JaGAr01 type seems not to be much difficult in the near future. However, some such problems as mentioned previously may be necessary to dissolve before this vaccine will be used in routine. 